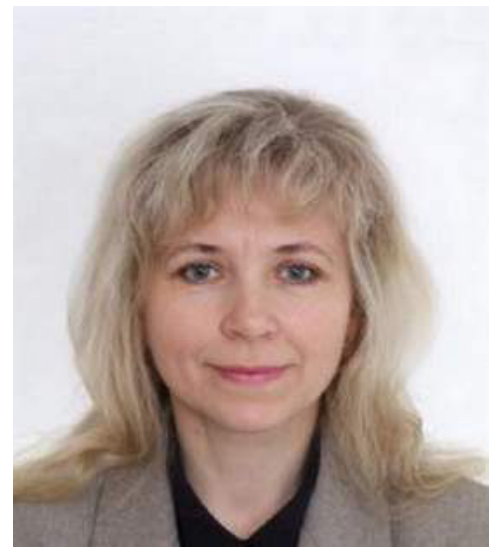

\section{Тетяна Потапчук,}

доктор педагогічних наук, професор кафедри теорії та методики дошкільної і спеціальної освіти, ДВНЗ «Прикарпатський національний університет імені Василя Стефраника» (м. Івано-Франківськ, Україна)

\section{Tetyana Potapchuk,}

Doctor of Education, Professor,

Department of Theory and Methods of Preschool

and Special Education,

Vasyl Stefanyk Precarpathian National University

(Ivano-Frankivsk, Ukraine)

tatvolod@ukr.net

Удк 37.011.3-051

\title{
КОМПЕТЕНТНІСНИЙ ПІДХІД У ПРОФЕСІЙНО-ПЕДАГОГІЧНОМУ САМОРОЗВИТКУ ВЧИТЕЛЯ
}

Анотація. У статті проаналізовано компетентнісний підхід, який базується в освіті на інтегрованих підходах до визначення результату освітньої діяльності, педагогічного процесу. Зазначено, що компетентнісну модель освітньої діяльності може реалізувати лише педагог, який сам відзначається високим рівнем професійної компетентності, здатністю до її постійного, ефективного розвитку та саморозвитку.

Ключові слова: компетентнісний підхід, компетентність, професійно-педагогічний саморозвиток вчителя, сучасна українська школа.

\section{COMPETENCY BASED APPROACH TO PROFESSIONAL AND PEDAGOGICAL SELF-IMPROVEMENT OF THE TEACHER}

Abstract. The article analyzes the competency based approach, which in education is based on integrated approaches to the definition of the result of educational activity, pedagogical process. It is noted that the competency based model of educational activity can be realized only by a teacher who himself has a high level of professional competence, ability to its constant, effective development and self-development.

Relevance of the problem. Modern trends in the socio-economic development of the state determine the need for professionals who are able to adapt to constantly changing conditions to work with continuously updated information flows. It is about specialists not only those who know and who can use their knowledge in standard, typical situations, but competent, capable of creativity, analytical thinking, personal, professional self-realization. The competency based educational paradigm is an objectively defined need to change the priorities of educational development, focusing on the peculiarities of the current socio-economic situation, the prospects for the development of the labor market.

The National Strategy for the Development of Education in Ukraine up to 2020 outlines the priority directions of a forwardlooking innovative development of a modern comprehensive educational institution as the basis for the development of the individual, society, nation and state, and outlines the main goals of its functioning and development:

- individual development of personality, disclosure of its potential;

- satisfaction of the needs of the country's economy in skilled labor;

- social integration, formation of an active member of the civil society;

- laying the foundations for lifelong learning.

Thus, the strategy of education development is naturally associated with the increasing tendencies to improve the level of personally oriented education, its individualization, continuity, which is made possible by increasing the proportion of selfdeveloping processes.

Aim and tasks - to analyze the theoretical basis of the competent approach in the teacher's professional training.

Objective: to find out the essence of the conceptual apparatus and the peculiarities of its content.

Research methods.

The method of system analysis was used for analysis, comparison and generalization of literary sources on the topic of the article, determining the level of professional competence of the teacher in his professional and pedagogical self-development. Results. Presenting main material. In the context of the development of competency based education, it is important not only to find out the essence of the conceptual apparatus, but also to show the features of its content, technological support, while emphasizing the self-education of the teacher as a significant component of the process. The notion of "competence" (from "competencia" - a range of issues with which a person is well-informed, possessing knowledge and experience), "competence" (from the Latin competence, which means proper, capable) are treated as readiness for activity at high 
quality standards. The concept of "competence", "competence" in education is complex and multidimensional, therefore, researchers, by examining different aspects and perspectives of the competency based approach at different levels of educational activity, offer different approaches to the interpretation of definitions.

Keywords: competency based approach, competence, teacher's professional and pedagogical self-development, modern Ukrainian school.

\section{ВСТУП}

Постановка проблеми. Сучасні тенденції соціально-економічного розвитку держави визначають потребу у професіоналах, здатних адаптуватися до умов, що постійно змінюються, до роботи з інформаційними потоками, які постійно оновлюються. Йдеться про спеціалістів не лише знаючих та тих, хто вміє використовувати свої знання у стандартних, типових ситуаціях, а компетентних, здатних до креативності, аналітичного мислення, особистісної, професійної самореалізації. Компетентнісна освітня парадигма - це об'єктивно задана потреба зміни пріоритетів розвитку освіти, орієнтуючись на особливості сучасної соціально-економічної ситуації, перспективи розвитку ринку праці.

Національною Стратегією розвитку освіти в Україні до 2020 року окреслено пріоритетні напрями випереджувальної інноваційної розбудови сучасного загальноосвітнього навчального закладу як основи розвитку особистості, суспільства, нації і держави та визначено основні цілі його функціонування й розвитку [6]:

- індивідуальний розвиток особистості, розкриття ії̈ потенціалу;

- задоволення потреб економіки країни у кваліфікованій робочій силі;

- соціальна інтеграція, формування активного члена громадянського суспільства;

- закладання основ для навчання впродовж життя.

Отож, стратегія розвитку освіти закономірно пов'язана з посиленням тенденцій до підвищення рівня особистісно орієнтованої освіти, її індивідуалізації, неперервності, що уможливлюється за рахунок підвищення питомої ваги саморозвивальних процесів.

Концепція розвитку сучасної української школи [5] має чітку компетентнісну спрямованість і визначає 10 ключових компетентностей, якими повинні оволодіти школярі в рамках загальноосвітньої діяльності, що мають значною мірою метапредметний характер і передбачають інтеграцію різних навчальних дисциплін. Особливо актуальною $€$ компетентність, пов'язана зі здатністю до ефективної навчальної діяльності (вміння вчитися), яка повинна стати, у тому числі, предметом саморозвитку особистості впродовж життя.

Компетентнісний підхід в освіті базується на інтегрованих (метапредметних, міждисциплінарних) підходах до визначення результату освітньої діяльності, педагогічного процесу. Вітчизняна система освіти починає забезпечувати якість, що відповідає уявленням «замовника», відповідно зазнають змін освітні стандарти як своєрідні формалізатори соціальних норм і потреб, освіта відповідає «вимогам соціоморфності, національним традиціям, соціально-економічному розвитку, національно-етнічному архетипу менталітету населення» [2, с. 6]. Закономірно, що компетентнісну модель освітньої діяльності може реалізувати лише педагог, який сам відзначається високим рівнем професійної компетентності, здатністю до ії постійного, ефективного розвитку та саморозвитку.

Аналіз останніх досліджень і публікацій. Теоретико-концептуальні підходи щодо формування професійної компетентності педагога містяться в роботах таких науковців, як Н. Бібік, Л. Ващенеко, С. Волошина, І. Зязюн, Н. Кузьміна, О. Локшина, О. Пометун, Г. Мельниченко, О. Овчарук, О. Савченко, В. Семиченко, Л. Семенець, С. Сисоєва, В. Сластьонін, О. Пехота, В. Ягупов та ін. Питання компетентнісного підходу до навчання як основи освітньої діяльності досліджували багато вітчизняних та зарубіжних учених (О. Антонова, Н. Боярчук, І. Зязюн, С. Іванова, В. Луговий, О. Савченко, Г. Селевко, М. Холодна, А. Хуторський, В. Шарко, та ін.).

МЕТА I ЗАВДАННЯ ДОсЛІДЖЕННЯ. Мета - проаналізувати теоретичні основи компетентнісного підходу у професійно-педагогічному саморозвитку вчителя.

Завдання: з'ясувати сутність понятійного апарату та особливості його змістового наповнення.

МЕТОДИ дослІджЕНня: метод системного аналізу використовувався для аналізу, зіставлення та узагальнення літературних джерел щодо теми статті, визначення рівня професійної компетентності вчителя в його професійно-педагогічному саморозвитку.

\section{РЕЗУЛЬТАТИ ДОСЛІДЖЕННЯ}

Як зазначають сучасні науковці, в умовах фахової підготовки спеціалістів компетентнісний підхід дає змогу:

- перейти у професійній освіті від його орієнтації на відтворення знань до їхнього застосування у більш досконалій фрормі;

- «зняти» диктат об'єкта (предмета) праці;

- покласти в основу стратегії освіти підвищення гнучкості її форм і методів на користь розширення можливості працевлаштування випускників вищих навчальних закладів і їх здатності виконувати розширений обсяг функцій та завдань;

- забезпечити пріоритет міждисциплінарно-інтегрованих вимог до результату освітнього процесу;

- пов'язати більш тісно мету освіти майбутніх фрахівців із ситуаціями їхньої самореалізації у світі профресійної праці;

- орієнтувати людську діяльність на нескінченну розмаїтість професійних і життєвих ситуацій [4]. 
У контексті розвитку компетентнісної освіти важливо не лише з'ясувати сутність понятійного апарату, а й особливості його змістового наповнення, технологічного забезпечення, притому акцентувавши увагу на самоосвітній діяльності вчителя як значущій складовій процесу. Поняття «компетенція» (від. лат. competencia - коло питань, з якими людина добре обізнана, володіє знаннями і досвідом), «компетентність» (від латинського competentis, що означає належний, здібний) трактуються як готовність до діяльності за високими стандартами якості. Поняття

«компетенція», «компетентність» в освіті складне і багатовимірне, тому науковці, досліджуючи різні аспекти та ракурси компетентнісного підходу на різних рівнях освітньої діяльності, пропонують різні підходи до трактування дефініцій.

У базових положеннях дослідники компетентнісної освіти базуються на європейських підходах, які визначають компетентність як «Загальні або ключові уміння, базові вміння, фундаментальні шляхи навчання, ключові кваліфікації, кроснавчальні вміння або навички, ключові уявлення, опори, опорні знання» (Міжнародна комісія Ради Європи - 1996 р.), «Здатність застосовувати знання й уміння, що забезпечує активне використання навчальних досягнень у нових ситуаціях» (Експерти Євросоюзу (Eurydice, 2002 р.) та ін. Дослідником Г. Селевко компетентність трактується як «інтегральна якість особистості, яка проявляється в її загальній здатності та готовності діяльності, що ґрунтується на знаннях та досвіді, які набуті в процесі навчання і соціалізації та орієнтовані на самостійну та успішну участь у діяльності [11, с. 139].

Академік Н. Бібік, диференціюючи поняття «компетентність» та «компетенція», стверджує, що «...компетентність цілісна, тобто ні знання, ні вміння, ні досвід діяльності самі по собі не є компетентністю. Компетенція на відміну від компетентності як особистісного утворення - відчужена від суб'єкта, наперед задана соціальна норма освітньої підготовки учня, вчителя, іншого спеціаліста, необхідна для його якісної продуктивної діяльності в певній сфері. Результатом набуття компетенцій є компетентність, що передбачає особистісну характеристику, ставлення до предмета діяльності. Компетенції виводяться як реальні вимоги до засвоєння учнями, студентами сукупності знань, способів діяльності, досвіду ставлення до певної галузі, якостей особистості, яка діє в певному соціумі [1]. М. Холодна вважає, що компетентність - це особливий тип організації предметно-специфічних знань, які дозволяють приймати ефективні рішення у відповідній галузі діяльності. На її думку, знання повинні відповідати таким вимогам: різноманітності (множина різних знань про різне); структурованості; гнучкості; оперативності і доступності; здатність до застосування знань в нових ситуаціях; категоріальний характер знань; володіння не тільки декларативними, але й процедурними та конструктивними знаннями; рефлексії, тобто знання про широту і глибину своїх знань [11, с. 207].

На думку О. Пометун, компетентнісний підхід в освіті пов'язаний з особистнісно орієнтованим і діяльнісним підходами до навчання. Він потребує трансформації змісту освіти. Його трансформація відповідно до компетентнісного підходу насамперед визначається принципово іншими принципами відбору й структурування, спрямованими на кінцевий результат освітнього процесу - набуття учнем компетентностей [8].

Академік О. Савченко вказує на те, що «тривалі наукові дискусії дали змогу вченим виокремити чотири базові характеристики поняття «компетентність». А саме: - використання компетентності завжди відбувається у певному контексті (скажімо, у конкретній навчальній ситуації); - компетентність завжди є результатом, вона характеризує те, що може зробити індивід, а не описує процес, під час якого він набув цю компетентність (наприклад, учень показує, що саме він уміє, а не розповідає: «Я читав, я писав...»); - для вимірювання здатності індивіда користуватися компетентністю потрібні чітко визначені та затверджені стандарти; - компетентність $€$ мірою того, що індивід може зробити у конкретно визначений час [9, с. 5].

Порівняльний аналіз найважливіших позицій у трактуваннях різних науковців дав можливість з'ясувати спільності та відмінності у їх головних характеристиках. Ми виділили два блоки аспектів, на яких базуються автори і які вказують на актуальність самоосвітньої діяльності у процесі їх фрормування.

1. Компетентність трактується як характеристика індивіда, інтегрованого в будь-яку діяльність, як базисна риса особистості, що буде проявлятися під час будь-якого виду діяльності індивіда. Йдеться про комплекс особистісних характеристик, що формуються впродовж життя і створюють передумови до формування компетентності (комплекс відповідних цінностей, наявність високого рівня мотивації до саморозвитку, прагнення до професіоналізму у відповідній галузі, націленість на продуктивність діяльності, здатність до саморегуляції, самоаналізу, рефлексії тощо. Отож, акцентується увага на особистісних якостях людини (учня, студента, професіонала). Закономірно, що формування особистісних якостей, включаючи мотивацію, цінності, як і здатність до самоуправління, реалізується лише через саморозвиток (особистісний, професійний), і тому завдання сучасної освіти на етапі переходу до компетентнісної освіти обумовлює потребу фрормування такої системи професійного розвитку вчителя, яка є сприятливою для переходу на рівень саморозвитку.

2. Компетентність визначається як комплекс необхідних знань, умінь, навичок, якими володіє суб'єкт освітньої, професійної діяльності, що забезпечують її успішність. Тут за основу береться розуміння, що кожна профресія і вид діяльності мають свій набір вимог до людини як суб'єкта її формування. При тому забезпечується особистісна орієнтованість знань, умінь, наявність власної методики та стилю їх використання. Отож, ідеться про формування професійної компетентності як професійного навчання, що реалізується на основі «я-концепції», яка не може бути формально запроваджена (одна для всіх), запозичена, а лише створена в процесі самоосвіти, саморозвитку. 
Поняття «компетенція», «компетентність» вивчаються на різних рівнях освітньої, професійної діяльності, адаптуючи їх змістово-технологічне забезпечення. Професійна компетентність більшістю дослідників трактується як складне системне утворення, що інтегрує знання, вміння, особистісні якості, особистісно орієнтовану методику та стиль діяльності, а також чітко виражену потребу в саморозвитку впродовж життя.

Так, І. Зязюн вважає, що «складниками професіоналізму у будь-якій професії є компетентність та озброєння системою вмінь» $[7$, с. 112].

Актуальність проблеми посилюється тим чинником, що компетентнісна освіта будь-якого рівня (школа, виш, післядипломна) передбачає тенденцію до переходу освіти на рівень самоосвіти, тобто фрормування здатності суб'єкта до освіти впродовж життя, яка реалізується за індивідуальною програмою, орієнтується на власний потенціал розвитку.

В. Ягупов визначає професійну компетентність як «підготовленість до здійснення певної професійної діяльності та наявність професійно важливих якостей фахівця, які сприяють цій діяльності» [12, с. 7].

На думку С. Іванової, профресійна компетентність - це здатність фрахівця від моменту початку своєї профресійної діяльності на рівні визначеного державою певного стандарту відповідати суспільним вимогам професії шляхом ефективної професійної діяльності та демонструвати належні особисті якості, мобілізуючи для цього відповідні знання, вміння, навички, емоції, ґрунтуючись на власній внутрішній мотивації, ставленнях, моральних і етичних цінностях та досвіді, усвідомлюючи обмеження у своїх знаннях і вміннях та акумулюючи інші ресурси для їх компенсації [3, с. 110].

Проаналізувавши та узагальнивши головні позиції дослідників компетентнісного підходу в професійній освіті, професійно-педагогічній (післядипломній) освіті та самоосвіті, було з'ясовано, що їх об'єднують наступні домінуючі характеристики:

1. Суб'єктність позиції фрахівця, що визначає здатність до системного, перманентного професійного, особистісного саморозвитку. Формування та розвиток професійних знань, умінь відбувається за особистісно орієнтованими технологіями, на основі «Я-концепції». Важливою $є$ наявність чіткої професійної та життєвої позиції, сорормованої на основі життєвого досвіду, загальної ерудованості, здатності до самоактуалізації тощо.

2. Варіативність. Компетентний професіонал спроможний ефективно адаптуватися до умов діяльності, що постійно змінюються, до конкретної ситуації, проаналізувавши ії та визначивши найбільш оптимальний варіант ії̈ вирішення.

Для цього він має володіти широким спектром необхідних знань, умінь та навичок, аналітичним мисленням, прогностичними, організаторськими, комунікативними та іншими вміннями, що визначають готовність до взаємодії.

За умов ринкової економіки така характеристика, як варіативність і гнучкість, динамічність професіонала, стає все більш важливою.

3. Комплекс особистісних якостей, що необхідні як для компетентнісного розвитку, так і для професійної діяльності безпосередньо. Профресіонал повинен володіти достатнім рівнем мотивації, бути здатним до аналітико-рефлексивної діяльності, поглибленого самоаналізу, визначення пріоритетних напрямів саморозвитку.

\section{ВИСНОВКИ ТА ПЕРСПЕКТИВИ ПОДАЛЬШИХ ДОСЛІДЖЕНЬ}

Отже, визначення сутності компетентнісного підходу в професійній освіті обумовлює загальний підхід та логіку формування професійної компетентності спеціаліста на основі комплексного підходу, що включає в себе професійну, особистісну складові. Тобто за умови посилення суб'єктності процесу професійного розвитку, саморозвитку важливим $€$ не тільки професійна складова (набуття необхідних практико-теоретичних умінь та навичок), а й особистісна: розвиток особистісних якостей, зокрема, таких, як здатність до самоактуалізації, рефлексії, організованість, високий рівень самоконтролю, емпатія тощо, виводить на новий якісний рівень як процес навчання, так і рівень професійної діяльності.

\section{СПИСОК ВИКОРИСТАНИХ ДЖЕРЕЛ}

[1] Бібік Н. М. Переваги і ризики запровадження компетентнісного підходу в шкільній освіті. Український педагогічний журнал. 2015. № 1. C. 47-58. URL: http://nbuv.gov.ua/UJRN/ukrpj_2015_1_8.

[2] Борисенков В. П. Значение своеобразия и оригинальности в культуре и человеке в условиях глобализации. Славянская педагогическая культура. 2010. № 9. С. 5-6.

[3] Іванова С. В. Функціональний підхід до визначення професійної компетентності вчителя біології та організація її вдосконалення в закладі післядипломної освіти. Вісник Житомирського державного університету імені Івана Франка. Серія : педагогічні науки. Житомир, 2008. С.8-12.

[4] Компетентнісний підхід у сучасній освіті : світовий досвід та українські перспективи: бібліотека з освітньої політики : монографія / Н. М. Бібік, Л. С. Ващенеко, О.І.Локшина та ін. ; за заг. ред. О. В. Овчарук. Київ : К.І.С., 2004. 112 с.

[5] Концепція «Нова українська школа». URL: http://mon.gov.ua/mon.pdf.

[6] Національна стратегія розвитку освіти в Україні на 2012-2021 роки. URL: http://www.meduniv.Iviv.ua/files/info/nats_strategia. pdf.

[7] Педагогічна майстерність / І. А. Зязюн, Л. В. Карамущенко, І. Ф. Кривонос та ін. ; за ред. І. А. Зязюна. Київ : Вища школа, 1997. 349 c.

[8] Пометун О. Дискусія українських педагогів навколо питань запровадження компетентністного підходу в українській освіті. Основна школа. 2005. Вип. 3-4. С.16-20. 
[9] Савченко О. Я. Ключові компетентності - інноваційний результат шкільної освіти. Рідна школа. 2011. № 8-9. C. 4-8. URL: http://nbuv.gov.ua/UJRN/rsh_2011_8-9_4.

[10] Селевко Г. Компетентности и их классификация. Народное образование. 2004. № 4. С. 138-143.

[11] Холодная М. А. Психология интеллекта. Парадоксы исследования. Санкт-Петербург : Питер, 2002. 272 с.

[12] Ягупов В. В., Свистун В. І. Компетентнісний підхід до підготовки фрахівців у системі вищої освіти. Наукові записки НаУКМА. Серія «Педагогічні, психологічні науки та соціальна робота». Київ, 2007. Т. 71. С. 3-8.

\section{REFERENCES (TRANSLATED AND TRANSLITERATED)}

[1] Bibik N. M. Perevaghy i ryzyky zaprovadzhennja kompetentnisnogho pidkhodu v shkiljnij osviti (Benefits and risks of introducing a competent approach in school education). Ukrajinsjkyj pedaghoghichnyj zhurnal. 2015. № $1 . \quad$ S. 47-58. URL:http://nbuv.gov.ua/ UJRN/ukrpj_2015_1_8. (in Ukrainian)

[2] Borysenkov V. P. Znachenye svoeobrazyja y oryghynaljnosty $v$ kuljture y cheloveke v uslovyjakh ghlobalyzacyy (The Importance of Originality and Originality in Culture and Man in the Context of Globalization). Slavjanskaja pedaghoghycheskaja kuljtura. 2010.

№ 9. S. 5-6. (in Russian)

[3] Ivanova S. V. Funkcionaljnyj pidkhid do vyznachennja profesijnoji kompetentnosti vchytelja biologhiji ta orghanizacija jiji vdoskonalennja $v$ zakladi pisljadyplomnoji osvity (Functional approach to the definition of the professional competence of the teacher of biology and the organization of its improvement in the institution of postgraduate education). Visnyk Zhytomyrsjkogho derzhavnogho universytetu imeni Ivana Franka. Serija : pedaghoghichni nauky. Zhytomyr, 2008. S.8-12. (in Ukrainian)

[4] Kompetentnisnyj pidkhid u suchasnij osviti : svitovyj dosvid ta ukrajinsjki perspektyvy (Competency approach in modern education: world experience and Ukrainian perspectives): biblioteka z osvitnjoji polityky : monoghrafija / N. M. Bibik, L. S. Vashheneko, O. I. Lokshyna ta in. ; za zagh. red. O. V. Ovcharuk. Kyjiv : K.I.S., 2004. 112 s. (in Ukrainian)

[5] Koncepcija «Nova ukrajinsjka shkola» (Concept "New Ukrainian School"). URL: http://mon.gov.ua/mon.pdf. (in Ukrainian)

[6] Nacionaljna strateghija rozvytku osvity v Ukrajini na 2012-2021 roky ( National Strategy for the Development of Education in Ukraine for 2012-2021). URL: http://www.meduniv.Iviv.ua/files/info/nats_strategia.pdf. (in Ukrainian)

[7] Pedaghoghichna majsternistj (Pedagogical skill) / I. A. Zjazjun, L. V. Karamushhenko, I. F. Kryvonos ta in. ; za red. I. A. Zjazjuna. Kyjiv : Vyshha shkola, 1997. 349 s. (in Ukrainian)

[8] Pometun O. Dyskusija ukrajinsjkykh pedaghoghiv navkolo pytanj zaprovadzhennja kompetentnistnogho pidkhodu $v$ ukrajinsjkij osviti (Discussion of Ukrainian teachers on the introduction of a competence-based approach in Ukrainian education). Osnovna shkola. 2005. Vyp. 3-4. S.16-20. (in Ukrainian)

[9] Savchenko O. Ja. Kljuchovi kompetentnosti - innovacijnyj rezuljtat shkiljnoji osvity . (Key competencies are an innovative result of school education). Ridna shkola. 2011. № 8-9. S. 4- 8. URL: http://nbuv.gov.ua/UJRN/rsh_2011_8-9_4. (in Ukrainian)

[10] Selevko Gh. Kompetentnosty y ykh klassyfykacyja (Competencies and their classification). Narodnoe obrazovanye. 2004. № 4. S. 138-143. (in Russian)

[11] Kholodnaja M. A. Psykhologhyja yntellekta. Paradoksy yssledovanyja (Psychology of the intellect. Paradoxes of research). Sankt- Peterburgh : Pyter, 2002. 272 s. (in Russian)

[12] Jaghupov V. V., Svystun V. I. Kompetentnisnyj pidkhid do pidghotovky fakhivciv u systemi vyshhoji osvity (Competent approach to the training of specialists in the system of higher education). Naukovi zapysky NaUKMA. Serija «Pedaghoghichni, psykhologhichni nauky ta socialjna robota». Kyjiv, 2007. T. 71. S. 3-8. (in Ukrainian) 